\title{
М.К. Чуркин
}

\section{РЕЦЕНЗИЯ : ЗАПОРОЖЧЕНКО Г.М. ГОРОДСКАЯ ПОТРЕБИТЕЛЬСКАЯ КООПЕРАЦИЯ В СИБИРИ В НАЧАЛЕ ХХ В.: ПОИСК ИДЕНТИЧНОСТИ И ОПЫТ ГРАЖДАНСКОГО САМОУПРАВЛЕНИЯ / ОТВ. РЕД. А.А. НИКОЛАЕВ ; ИН-Т ИСТОРИИ СИБ. ОТД-НИЯ РОС. АКАД. НАУК. НОВОСИБИРСК : СИБПРИНТ, 2015. 540 с.}

Обращение Г.М. Запорожченко к теме кооперативного движения и, в частности, организации и моделям функционирования городской потребительской кооперации Сибири в процессе модернизационного перехода достаточно рельефно характеризует состояние современной историографической ситуации. Очевидно, что в настоящий момент историческая наука пребывает в фазе переопределения предмета и методологических подходов к исследованию прошлого, что сопровождается расширением и усложнением тематического спектра и проблемного поля исследовательской деятельности историка, привлечением новых научноисследовательских практик.

В данном отношении рецензируемая монография Г.М. Запорожченко в полной мере вписывается в контекст новой историографической ситуации, что определяет актуальность избранной научной проблематики.

Во-первых, форсированная модернизация в Российской империи на рубеже XIX-XX вв., сопровождавшаяся высокой степенью концентрации капитала и производства, актуализировала активное вмешательство государственных структур в сферу экономических и, как следствие, общественных отношений. Таким образом, через обращение к проблеме институциализации городской потребительской кооперации у историка появляется возможность смещения акцентов в исследовании вопроса от сугубо экономических оценок процесса к социокультурной рефлексии взаимоотношений государства и общества. По определению Г.М. Запорожченко, в условиях монархической государственности потребительские кооперативы руководствовались принципами демократизма и общедоступности, тем самым выполняя функцию гражданского союза, занимавшего промежуточное положение между обществом, с одной стороны, и государством - с другой. В результате такой диспозиции в фокусе внимания исследователя оказываются коммуникативные связи, в том числе и те субъективные факторы, которые создают социальную атмосферу в отношениях между людьми и, в конечном итоге, формируют пространство культурного измерения исторического процесса.

Во-вторых, концессионная форма организации потребительской кооперации в России и регионах наглядно демонстрирует включенность имперских структур в социально-политические и экономические процессы. В данной связи проблема, избранная автором, вписывается в концептуальные рамки проекта «новой истории империи» (Герасимов, Могильнер, Ремнёв и др.) не только потому, что кооперация в условиях освоения восточных окраин являлась важным инструментом имперской политики, но и вследствие наличия региональной специфики. Кооперативное движение в Сибири рефлексировалось в имперском дискурсе как одно из проявлений сибирской региональной идентичности. Всё это, в конечном счёте, способствовало ускоренному формированию гражданского общества на окраинах страны, существенной коррекции представлений имперских властей о цели и задачах колонизации, видоизменению практик имперской инкорпорации Сибири в общегосударственный конструкт.

Г.М. Запорожченко удалось чётко обозначить интеллектуальный ландшафт проекта, зафиксировав историографический опыт рефлексии научной проблемы. Это позволило автору выявить лакуны в изучении вопроса, наметив собственный оригинальный вектор исследования: становление городской потребительской кооперации Сибири в контекстных обстоятельствах модернизации и формирования гражданского общества. Автор монографии достоверность полученных результатов подтверждает широким кругом разноплановых источников, аккомодированных в исследовательский контекст. Привлечение к работе текстов нормативно-правового, справочно-статистического характера, в сочетании с документами официального делопроизводства, материалами периодической печати и фрагментарно эго-источниками, предоставило автору благоприятную возможность сфокусировать внимание на экономических аспектах существования потребительской кооперации Сибири и реконструировать модели функционирования института городской кооперации в социокультурных параметрах региона.

Следует отметить высокий уровень научной новизны исследования. Г.М. Запорожченко осуществлено самостоятельное оригинальное научное исследование, в котором представлены всесторонние оценки процесса генезиса, институциализации и развития городской потребительской кооперации Сибири на рубеже XIX начала XX в. Элементы научной новизны монографии в значительной степени усилены функциональным ме- 
тодологическим инструментарием, посредством обращения к принципам и подходам, разработанным в предметном пространстве формационной, цивилизационной и модернизационной научно-исследовательских парадигм. Авторским новаторством, безусловно, можно считать разработку модели функционирования потребительской кооперации в городском континууме Сибири. Необходимо добавить, что широкоформатное осмысление деятельности потребительских кооперативов Сибири в условиях модернизации и бурного развития государственного капитализма открывает известные перспективы для корректировки традиционного взгляда на регион как исключительно экономическую колонию Российской империи, в силу исторических обстоятельств обделённую атрибуциями начал гражданственности.

В теоретическом плане монография Г.М. Запорожченко вносит значительный вклад в осмысление имманентных характеристик кооперативного движения вообще и городской потребительской кооперации в частности. Автору удалось реконструировать модель функционирования потребительской кооперации с учётом присущих ей самоорганизующих характеристик. Тем самым были наглядно продемонстрированы культурсоставляющие элементы и культуртрегерские возможности кооперации в плане организации социокультурного пространства города и региона, установления каналов социальной коммуникации и собственно коммуникативных контактов. Важным теоретическим выводом следует признать авторский тезис о применимости к изучению конкретно-исторических задач концепта «гражданское общество», что реализовалось не только в подтверждении теории Манфреда Хильдмайера о широком распространении в дореволюционной России идеалов гражданского общества, но и реальных признаках такового в кооперативной среде Сибири.

Наряду с отмеченными достоинствами работы имеет смысл остановиться на некоторых недоработках и полемических моментах исследования, отметив при этом, что сочинение Г.М. Запорожченко располагает к дискуссии.

Стоит обратить внимание на важное обстоятельство, сообразно с которым научная монография является цельным произведением, связанным единым интеллектуальным ландшафтом с присущим ему методологическим разнообразием. В данной связи конструирование исследовательского пространства работы вокруг исключительно формационного, цивилизационного и модернизационного подходов представляется серьёзно сужающим предметное поле исследования. Совершенно очевидно, что в основной части монографии автор, размышляя о процессах становления и развития городской потребительской кооперации в Сибири, неизбежно выходит на проблемы имперского участия в организации кооперативного дела, включения широкого круга акторов в обсуждение данной проблемы, выработки практических решений в вопросе кооперативного строительства, определения роли и места городских кооперативов в имперском проекте колонизации.

Апелляции к наработкам и исследовательским практикам «новой истории империи», на наш взгляд, могли удачно соотнестись с подходами, апробированными адептами «новой локальной истории». Тем более что в монографии отчётливо вырисовываются контуры кооперации как локального сообщества с явными признаками социальной и гражданской идентичности. Это важно, потому что концепт «локальное сообщество» выносит в центр внимания сферу общественной самоорганизации и ставит вопрос, в какой степени и благодаря каким практикам и механизмам конституировался вне привычных стратификационных категорий сословий и класса самоорганизующийся общественный ансамбль.

В данном отношении существенным является и то, что гражданская идентичность, которая в кооперативной среде в силу её демократического формата формировалась наиболее интенсивно, обладает отличительным признаком «проявляться» в языке. Увы, но работа Г.М. Запорожченко в большей мере оказалась сориентирована в направлении вскрытия деятельностного аспекта функционирования городской потребительской кооперации. Примечательно, что в преамбуле к разделу «Обзор источников» эго-материалы вообще не упомянуты как вид (С. 53). Между тем в заключительной части данного фрагмента неожиданным образом появляются записки деятелей кооперации Н.А. Рожкова, А.А. Байкалова и др. (С. 56), не удостоенные тщательного разбора и анализа. Фактическое привлечение источников мемуарного характера позволило бы автору вести речь не только и не столько об экономическом эффекте кооперации, но и о формировании коммуникативного пространства кооперативного движения и, как следствие, кооперативной идентичности как части идентичности гражданской, ответить на вопрос, насколько «молчаливой» или, напротив, «говорящей» являлась категория кооператоров.

По мнению рецензента, в монографии остался нерешённым целый ряд вопросов, что вряд ли можно поставить в вину автору (нельзя объять необъятное). Более того, наличие таковых свидетельствует о достаточно мощном научном потенциале работы и её дальнейших перспективах. Выделим наиболее существенные:

1. Вне поля зрения Г.М. Запорожченко оказались этнические и конфессиональные аспекты функционирования городских потребительских кооперативов. Каким образом национальные и конфессиональные группы, включённые в канву кооперативного дела в городах, определяли характер деятельности данного института вообще, а также в относительно спокойные периоды и годы социальных потрясений? Насколько комфортно ощущали себя представители этих групп в условиях концессионных принципов организации кооперативного движения и т.д.? 
2. За кадром осталась проблема специфики сибирского города. Автор представила детальную характеристику облика городов, при этом достаточно слабо обоснованным остаётся вопрос о новом качестве городов региона в связи с колонизационной программой имперских властей. Именно крупные сибирские города оказывались в эпицентре политики колонизации, здесь сосредотачивались профессиональные научные и образовательные кадры, проводились работы по подготовке и проведению экспертиз территорий освоения (см. деятельность Западносибирского отдела Императорского Русского географического общества в г. Омске), тем самым оформлялась особая социокультурная среда, являвшаяся вполне благоприятной для становления городской потребительской кооперации родчельского типа.

Подводя итоги, отметим, что высказанные замечания носят принципиальный и рекомендательный характер, не отменяют высокого качества, своевременности и научной актуальности монографии, поскольку в ней представлены способы решения важных задач, направленных на выявление факторов и условий институционализации и функционирования городской потребительской кооперации в Сибири в контексте модернизационных процессов конца XIX - начала $\mathrm{XX}$ в., что крайне существенно для приращения новых научных знаний в сфере экономической и социокультурной истории. A.A. NIKOLAEV ; INSTITUTE OF HISTORY OF SIBERIAN BRANCH OF RAS. NOVOSIBIRSK : SIBPRINT, 2015.540 p. 